\title{
Descriptive analysis of social media adoption and utilization in AACSB schools
}

\author{
Indira Rani Priyadarshini Srikoo, Governors State University, Email: priyasirp28@gmail.com \\ Dr. Dalsang Chung, Governors State University,Email: dchung@govst.edu
}

\begin{abstract}
Technology is constantly evolving and its advancements are taking us to new peaks across the globe. Social media networking has made a remarkable impact, connecting people around the world, making a difference in every field such as business, education, healthcare, and so on. Specifically, in the case of universities, there is a radical increase of social media usage by the millennial generations for gathering information about the university brand, technology, and education. The purpose of this study is to measure the adoption and utilization of social media with respect to various characteristics of universities. To that end, data is collected from the AACSB International website and is subject to descriptive analysis. ANOVA and regression analysis used to observe the university trends in adopting four social media platforms, specifically, Facebook, Twitter, LinkedIn, and Instagram. The results show that the public universities in both business \& accounting sectors adopted social media significantly more than other groups, and that LinkedIn is the predominant communication social network among such universities. Furthermore, the ANOVA and regression analysis predict that university characteristics like region, type, level, and program show similar levels of significance on Facebook, Twitter, and LinkedIn while enrollment and operating budget show significant impact on the number of likes or followers respectively.
\end{abstract}

Keywords: social media; technology; university characteristics; regression analysis, ANOVA test, AACSB schools

\section{Introduction}

Today, around seven in every ten Americans use social media to connect with one another, to learn about a new technology, and to explore the dynamic contents of the world. During the year 2005, when few research organizations began tracking social media adoption, only 5\% of American adults used at least one of the platforms. There is a significant increase by the year 2011 and by now $69 \%$ of the Americans use some type of social media (FACTSHEET, 2018).

It is not an exaggeration that a lot of colleges and universities are using social media to attract students, to interact with students and stay connected with the alumni. This platform has been a key for the education system and has successfully connected not only prospective students but also prospective parents (Cannon, 2015). When students want a higher education and an excellent program, they start by searching for a university where they can get all types of facilities and the best faculty. Earlier, they needed to visit the campus and get booklets to get the information. Now because of social media, the students can now easily connect with the university faculty, staff, and alumni $24 \times 7$. Likewise, owing to the student's needs, universities have also started using social media platforms like Facebook, Twitter, LinkedIn \& Instagram to share their campus culture with prospective students and their parents, reaching millions of international students who can now come to the United States to pursue their education and get various degrees and specializations from their dream universities (Ridley, 2016) 


\section{Issues in Information Systems}

Volume 22, Issue 4, pp. 126-142, 2021

Social media is a powerful technological tool that penetrated into the global market. from the point of view of universities, they use social media for marketing university events, students' innovative work, schedules, and so on, whereas, the public use it to know about a university's programs, events, reviews and ratings. This enables a two-way interaction between the universities and the potential students, parents, in addition to the traditional means of visiting a university's website and forming an opinion (Ridley, 2016).

In short, social media has radically transformed the way it communicates across the world in this new digital era. The significant rise in social media usage adopted in many sectors. Especially in the field of education, the adoption and utilization of new technologies has transformed the educational system into a different dimension (Griffis et al., 2014). In this cross-sectional study, in order to measure the adoption and utilization of social media in the universities, data collected from the AACSB International for a descriptive analysis using ANOVA and regression. The dataset being large, allows us to predict trends of AACSB accredited universities' characteristics, extracted from the university profiles.

We explore how universities are using social media platforms to strengthen their communications and to build a strong social network. This can be achieved by analyzing the social media pages of different universities for a variety of university characteristics like state, region, type (public \& private), student enrollment, faculty full time, faculty (FT+PT), operating budget, level of study, whether it's undergraduate, graduate or both, Analytics Program (Yes or No), and finally the AACSB accreditation for business, accounting, or both. The influence of these characteristics on universities' adoption and utilization of a few popular social media platforms then forms the crux of this work.

This study performs cross sectional review of University related activities based on four social media platforms: Facebook, Twitter, LinkedIn, and Instagram. We will select the universities that hold AACSB Accreditation (The Association to Advance Collegiate Schools of Business) and extract data of each university from the four social media platforms. Moreover, with the help of results, we do a descriptive analysis of universities on how a university's characteristics are trending and assess the overall impact of social media on the educational system.

Facebook is a very popular social media tool that can be used to create online groups and communities so that it becomes easy for the students and faculties to get information regarding events and programs, where visitors get a lot of information about the university and can easily connect with the existing students (Karadkar, 2015). On the other hand, Twitter uses small telegraphic and important messages that a university wants to broadcast an announcement/share information. LinkedIn is another very important social media tool especially for university students because it connects them with their friends, alumni, as well as potential corporate and non-corporate employers. Finally, Instagram is an internet-based photosharing platform that allows people to share their pictures and videos. These social media platforms make it very easy to reach out to prospective students. Today, when students join a university, the first thing they typically do is to follow the university's Facebook, Twitter and Instagram accounts, while initiating a connection with its LinkedIn group. This enables universities to share information with the prospective students, on why they should join the university, to inform current students of any upcoming university events/programs and to inform alumni of any events that they can be part of the gathering. Secondly, these days more and more students are using social media for up-to-date information; even the universities prefer publishing the updated news and information on social media rather than on the websites.

Therefore, there is no doubt that social media has enlightened the lives of people with the power of knowledge \& information, turning them into global citizens. In addition, it is more impactful for students and youth. Students can share \& get information from any geographical location in the world even in a pandemic situation that the world is facing currently due to COVID19. In an article written by Doug Ridley 


\section{Issues in Information Systems}

Volume 22, Issue 4, pp. 126-142, 2021

in 2016 stated, "Using the power of different networks and engaging content, schools are using social media to attract students, interact with current students and stay connected with alumni". That is possible because of the social media platforms like Facebook, Instagram, Twitter, and LinkedIn etc. They offer many advantages such as ease/freedom of approach, a unique learning experience, and facilitate faster innovations. Students use them to socialize, build strong networking, make new friends, and comment on people's lives, thereby creating their own new digital identity. Secondly, when it comes to learning exposure, the students can share knowledge $\&$ new ideas that enhance their skills. In addition, it found that the students who use social media frequently are becoming more and more innovative. This is due to the incredible exposure of knowledge they get in the social media platforms. Especially when it comes to doing new projects, or landing internships \& jobs, they get to consult with knowledgeable and experienced people, which helps them, improve their skills and personalities (Cannon, 2015).

Effective eLearning can be using social media platforms in universities. Nowadays, universities offer online courses to make learning more accessible for students who live far from the campuses. For example, on Facebook, instructors can make closed or open groups and upload online teaching materials, assignments, videos \& share relevant links with the students. Similarly, Twitter may use eLearning - although its major limitation is the 140 characters post limit. However, it may be useful for micro learning (MacArthur, 2017). Moreover, although Instagram has a 15 second limit on the length of videos/pictures, one can use it for cross posting the study materials and contents to different audiences. LinkedIn, on the other hand, is all about the student's professional life. There are many benefits of having a descriptive LinkedIn profile. Universities can therefore teach their students to make a good LinkedIn profile before they graduate to maximize their chances of landing their dream jobs.

Learning how social media platforms shape the lives of students can make a difference on universities' culture and impact helps in benchmarking and HLC accreditation process. This study provides an initial research on the utilization of social media in universities and the various characteristics affecting this usage. For any kind of university accreditation (HLC, AACSB, and so on), the enrollment and engagement of students, faculty, staff, and community play a significant role in sustaining the accreditation and in providing room for continuous improvement. The findings in this study help universities identify characteristics and develop strategies in improving exactly that. Social media platforms not only make the universities look more reputed, but can also spread knowledge and information widely (Bernardo, 2015). There is no doubt that social media has the potential to become the primary channel of communication among the universities in the United States (Ridley, 2016). Therefore, for researchers, this study paves a path in an untapped area of research for better understanding the factors/characteristics influencing social media usage in universities. Further, researchers can work on formally establishing the efficacy of social media usage for the purposes of communication, understanding the campus culture and climate, enrollment, and engagement by the universities, students, faculty, and staff.

Thus, the aim of this study is to analyze the adoption and utilization of social media usage across the United States universities. Here the university characteristics such as state, type (public \& private), student enrollment, faculty full time, faculty (FT+PT), operating budget, level of study whether its undergraduate, graduate or both, Analytics Program (Yes or No), the AACSB accreditation for business, accounting or both, which are rationally proportionate with respect to each other. With the help of descriptive analysis using ANOVA regression analysis, the data collected from AACSB website (Griffis et al., 2014). For this cross sectional study, four social media platforms considered - Facebook, Twitter, Instagram, and LinkedIn. In each of these social media platforms, the number of likes and followers are collected and analyzed to understand the trend of each AACSB accredited university in the United States. 


\section{Issues in Information Systems}

Volume 22, Issue 4, pp. 126-142, 2021

\section{Social Media Platforms:}

The presence of social media creates valuable benefits to the universities and colleges. In an article by the bestcolleges.com published that "The three largest platforms, Facebook, Instagram and Twitter, boast over 2.2 billion users worldwide, many of whom are in their late teens and early 20's"( Hashim, H., Ahmad, B. E., Abdullah Baharum \& M. A., Ismail, M. R., 2018). For this study, considering LinkedIn in addition to the top three social media platforms.

\section{Facebook}

Facebook is a social networking site popular among all the generations. Facebook applications are present in most smart phones across the globe. According to recent statistics, there are 2.13 billion monthly active users across the world for Q4 2017 that means an increase of 14 percent year over year. With such a huge popularity, Facebook tops among all the social media networks (Philips, 2007). It supports features such as status update, photos/videos sharing, messenger and story updates. Before the invention of Facebook, people used to communicate via mails and emails, not so interactive means of communication. Later, Facebook made it so easy for people to communicate with one another and to build new social connections. One can make new friends globally through Facebook. The platform facilitated incredible growth in every field such as health, education, business, entertainment, and so on. It is especially popular among the students and the universities (Wang, Chen \& Liang, 2011). Today, many educational institutions have adopted Facebook. They typically use it to highlight the university's image and popularity among various domains. They also use it to reach targeted groups of people to increase student enrollment. The posts cover a variety of topics like infrastructure, faculty, programs offered, events, guest lectures, and so on. Generally, when someone visits a university, they can check-in on the platform and can give feedback about their experience in the form of likes or comments on the university's page. Once they start like a university's home page, they start receiving its news feed/posts shared on the page. All these features make Facebook a popular platform for universities to reach students globally, build an effective community, and maintain their reputation.-

\section{Twitter}

Twitter is a micro blogging site that imposes a maximum of 140-character limit per message on the content posted on its platform. Though on November 7, 2017, that limit doubled to 280, for almost all languages other than Chinese, Korean \& Japanese (MacArthur, 2017). In Twitter, people can post tweets once they register as a user. Jack Dorsey, Biz Stone \& Evan Williams (PICARD, 2011), founded twitter. The idea behind Twitter conceptualized in the year of 2006, and Flickr; a photo-sharing service, inspired the name of this social media platform. Today, around 200 million users use Twitter and 460,000 new Twitter accounts are opened daily (PICARD, 2011). With a net worth of more than $\$ 5$ billion, Twitter is not only making profit but also influencing the society positively. People user Twitter not only to update their stories but also to comment about the day-to-day trending topics using hashtags (a string of characters prefixed by the symbol '\#'). It helps in publicizing important information very briefly with just one tweet. This feature transformed businesses across the world; with the hashtags increasingly used for marketing products, for opinionating about popular topics, for communication between employees \& their customers. For example, customers of a business can give it a review with just a single tweet, enabling the businesses to be smarter and agile. With such powerful features, Twitter is reshaping the world of media, politics, and education. Twitter can be extremely helpful for students, university faculty and for parents. Students typically clear their doubts by tweeting about them and getting answers from many experts. Similarly, when a student or a parent is looking for a suitable university, they can get a definite idea about the university from the university's official Twitter account. Though there are people who do not like twitter because the length of 


\section{Issues in Information Systems}

Volume 22, Issue 4, pp. 126-142, 2021

a post is restricted to only a few characters, it remains an extremely effective micro educational tool where one can post concepts using short but apt tweets. In the modern world, where people rarely have the time or patience for lengthy posts and messages, short and brief messages keep the essence.

\section{LinkedIn}

LinkedIn is a social networking web site that is more professional oriented. Unlike other social media platforms such as Facebook, Instagram \& Twitter, LinkedIn meant for connecting people in a professional setting. It focuses on a person's professional network and connections. Once registered, users on this platform must create their own professional profiles. Registration is free and allows the users to maintain their own profile capturing details of their professional career, education, skillset, enabling prospective employers to discover users who can fill job vacancies at their respective companies. This is one of the most popular platforms to discover new professional connections and get recommendations from a company or an employer (Gregersen, 2011). Today, it has almost 467 million users. LinkedIn helps the users to explore the business communities and lets them discover new job opportunities befitting their skillset. This social networking website helps students in boosting their career prospects and improving performances professionally (Montoneri, 2013). It not only enhances the career growth of the students but also helps universities broaden their reputation. Therefore, LinkedIn is an essential social networking platform that every university should be a part of to form a professional network. Undoubtedly, today, most universities are adopting LinkedIn and are encouraging their students to strengthen their professional presence by doing the same.

\section{Methodology}

\section{Study Design}

This study depicts a cross-sectional review of universities in the United States of America. Here, four of the most popular social media platforms are considered, namely, Facebook, Twitter, Instagram, and LinkedIn; to analyze adoption and utilization of social media among AACSB accredited US universities using ANOVA and regression analysis on university characteristics.

\section{Study Population}

All the universities considered by selecting USA as the region for AACSB universities. Then characteristics such as region, type (public \& private), student enrollment, faculty full time, faculty (FT+PT), operating budget, level of study whether its undergraduate, graduate or both, Analytics Program (Yes or No) and finally the AACSB accreditation for business, accounting or both are then extracted from the university social media profiles listed on their websites. The influence of these features on a university's social media adoption and utilization then analyzed by means of statistical analysis. Adoption here in this context defines as whether each university has an account on social media, whereas, utilization defined as the activity of a university on its social media account. Facebook, Twitter \& Instagram allow the universities and students to post contents, like, and comment, whereas, LinkedIn focuses on professional networking, jobs, and internships.

\section{Data Collection}

On the AACSB website, the university profiles are associated with the universities in its accredited list. For each university, the likes/followers in each social media platforms are extracted via manual scraping number of account likes on Facebook, no of followers in Twitter, Instagram, and LinkedIn. That is, official 


\section{Issues in Information Systems}

Volume 22, Issue 4, pp. 126-142, 2021

website information extracted for each university through the AACSB search engine, using which; corresponding social media accounts on each platform was determined. Because universities typically have multiple accounts on social media on one platform, the social media account for each of the universities in their websites as mentioned are considered as a primary representative of the university's existence on each of the social media platforms.

All these extracted values taken in a MS Excel sheet, where the ratio calculates with the number of likes/ followers' value to total number of students enrolled. This excel sheet is then loaded into SPSS to compute median, IQR and regression testing to get the t-test and p-test values; ANOVA test is used to know the Fvalues and corresponding $\operatorname{Pr}>\mathrm{F}$ values for significance. Finally, all the required data was manually extracted from each of the social media accounts for over a 1-month period (March 2018).

\section{Results}

\section{Adoption}

Of the total 526 US AACSB accredited universities identified, the adoption of social media websites varied across platforms and out of which only 448 universities worth of data was usable for this research. For the remaining 78 universities, the extracted data was not usable because of a variety of issues such as login constraints, partial social media profiles, and so on.

\section{Utilization}

As discussed earlier, utilization outlined how actively a university uses social media platforms. To analyze the utilization of a social media platform, all four characteristics are considered - region, Type (Public or Private), Level (Graduate, undergraduate or both) \& finally programs (business \& Accounting). Table1 below displays the magnitude of social media utilization differentiated by university characteristics. Public, graduate, both (UG \& GR) and both (business \& accounting) had significantly more utilization of social media than their comparison groups across all the four social media platforms. First, considering the region, southwest has more Facebook likes \& Instagram followers, while Midwest region has more Twitter \& LinkedIn followers. Northeast has the least number of Facebook likes and Twitter followers whereas Midwest and Southeast has the least number of followers in case of Instagram \& LinkedIn respectively. Secondly, considering type (public \& private), Public universities have more Facebook likes, a greater number of followers for Twitter, Instagram \& LinkedIn in comparison to the private universities. Now considering the level (GR, UG or both), the universities offering both graduate and undergraduate level of study are more popular on Facebook and Twitter, whereas, only graduate schools are popular on Instagram \& LinkedIn. Finally, looking at the Programs (Business \& Accounting), universities offering both the programs have popularity on all the four social media platforms. The magnitude score below calculated with median and IQR scores which are taken by uploading the excel spreadsheet in SPSS tool showing the values for respective university's characteristics giving an overall value to each variable (ex: Type) and sub-variable (ex: Public \& Private) underneath. Therefore, public universities found to be more popular in social media. For example, Public universities had a median of 29255(IQR 11912-57822) versus median 17974.5(IQR 9966-26662) Facebook likes, median 9202(IQR 4365-29400) versus 7622.5(IQR 4233-14668) median Twitter followers, median 6711(IQR 2409-15100) versus 5862 (2374-11042.5) Instagram followers and median 43607 (IQR 21923-93001) versus median 25673.5 (IQR 14902.5-43551) LinkedIn followers. Furthermore, universities which offer both business \& accounting programs had a median of 42636.5(IQR 7869-83514.0) Facebook likes, median 15700(IQR 5276-61826) Twitter followers, median 11300(IQR 4139-26000) Instagram followers, and median 68370 (IQR 29518-140424) LinkedIn followers. 


\section{Issues in Information Systems}

Volume 22, Issue 4, pp. 126-142, 2021

Table1: Magnitude of social media utilization relative to university characteristics for Facebook, Twitter, Instagram, and LinkedIn

\begin{tabular}{|c|c|c|c|c|c|c|c|c|}
\hline \multirow{2}{*}{$\begin{array}{l}\text { Social } \\
\text { media } \\
\text { Platform }\end{array}$} & \multicolumn{2}{|c|}{ Facebook } & \multicolumn{2}{|l|}{ Twitter } & \multicolumn{2}{|c|}{ Instagram } & \multicolumn{2}{|c|}{ LinkedIn } \\
\hline & Median & IQR & Median & IQR & Median & IQR & Median & IQR \\
\hline \multicolumn{9}{|l|}{ Region } \\
\hline Southwest & 29334 & $\begin{array}{l}16276- \\
81334\end{array}$ & 14641 & $\begin{array}{l}4365- \\
63300\end{array}$ & 8689 & $\begin{array}{l}3214- \\
22200\end{array}$ & 43676 & $\begin{array}{l}16411- \\
104988\end{array}$ \\
\hline Southeast & 26190.5 & $\begin{array}{l}11446- \\
500816\end{array}$ & 9093 & $\begin{array}{l}4058- \\
22142\end{array}$ & 6636 & $\begin{array}{l}3070- \\
12598\end{array}$ & 29630.5 & $\begin{array}{l}12951- \\
50467\end{array}$ \\
\hline West & 26221 & $\begin{array}{l}10612- \\
51701\end{array}$ & 9386.5 & $\begin{array}{l}5308- \\
25250\end{array}$ & 7646 & $\begin{array}{l}3111- \\
16855\end{array}$ & 46450.5 & $\begin{array}{l}17045- \\
80987.5\end{array}$ \\
\hline Midwest & 23970.5 & $\begin{array}{l}6909.5- \\
43353.0\end{array}$ & 23406.8 & $\begin{array}{l}4301- \\
27200\end{array}$ & 3905 & $\begin{array}{l}1974- \\
12642\end{array}$ & 48046 & $\begin{array}{l}25654- \\
98329\end{array}$ \\
\hline Northeast & 19633 & $\begin{array}{l}12024- \\
29269\end{array}$ & 7410.5 & $\begin{array}{l}3980- \\
13100\end{array}$ & 6007.5 & $\begin{array}{l}2038.5- \\
10526.5\end{array}$ & 34950 & $\begin{array}{l}18506 .- \\
54487\end{array}$ \\
\hline \multicolumn{9}{|l|}{ Type } \\
\hline Private & 17974.5 & $\begin{array}{l}9966- \\
26662\end{array}$ & 7622.5 & $\begin{array}{l}4233- \\
14668\end{array}$ & 5862 & $\begin{array}{l}2374- \\
11042.5\end{array}$ & 25673.5 & $\begin{array}{l}14902.5- \\
43551\end{array}$ \\
\hline Public & 29255 & $\begin{array}{l}11912- \\
57822\end{array}$ & 9202 & $\begin{array}{l}4365- \\
29400\end{array}$ & 6711 & $\begin{array}{l}2409- \\
15100\end{array}$ & 43607 & $\begin{array}{l}21923- \\
93001\end{array}$ \\
\hline \multicolumn{9}{|l|}{ Level } \\
\hline Both & 25491 & $\begin{array}{l}10547- \\
51319\end{array}$ & 9099 & $\begin{array}{l}4465.5- \\
24086.5\end{array}$ & 6199 & $\begin{array}{l}2409- \\
13600\end{array}$ & 38105 & $\begin{array}{l}18582- \\
79267\end{array}$ \\
\hline GR & 20776 & $\begin{array}{l}10445.5- \\
46845.5\end{array}$ & 8833.5 & $\begin{array}{l}2353- \\
33100\end{array}$ & 7286.5 & $\begin{array}{l}2364.5- \\
13190\end{array}$ & 44981 & $\begin{array}{l}17103- \\
110886\end{array}$ \\
\hline UG & 16354 & $\begin{array}{l}11906- \\
26519\end{array}$ & 5589 & $\begin{array}{l}3743- \\
7650\end{array}$ & 4088 & $\begin{array}{l}2490- \\
7083\end{array}$ & 19019.5 & $\begin{array}{l}12909- \\
26780\end{array}$ \\
\hline \multicolumn{9}{|l|}{ Program } \\
\hline Both & 42636.5 & $\begin{array}{l}7869- \\
83514.0\end{array}$ & 15700 & $\begin{array}{l}5276- \\
61826\end{array}$ & 11300 & $\begin{array}{l}4139- \\
26000\end{array}$ & 68370 & $\begin{array}{l}29518- \\
140424\end{array}$ \\
\hline Business & 20449 & $\begin{array}{l}11379- \\
33984\end{array}$ & 7355.5 & $\begin{array}{l}4233- \\
13100\end{array}$ & 5060.5 & $\begin{array}{l}2187- \\
9030\end{array}$ & 29969 & $\begin{array}{l}15976- \\
46616\end{array}$ \\
\hline
\end{tabular}




\section{Issues in Information Systems}

Volume 22, Issue 4, pp. 126-142, 2021

Table2: Regression of social media utilization relative to university characteristics

\begin{tabular}{|c|c|c|c|c|c|}
\hline Social media Platform & Parameter Estimate & Std Err & t- value & $\mathbf{P}$ & Significance \\
\hline \multicolumn{6}{|l|}{ Facebook } \\
\hline Enrollment & 8.4769 & 3.7394 & 2.27 & 0.0235 & Yes \\
\hline Faculty FT & -112.9708 & 423.197 & -0.27 & 0.7896 & No \\
\hline Faculty FTPT & -239.4429 & 331.159 & -0.72 & 0.47 & No \\
\hline Operating Budget & 0.0016 & 0.0002 & 6.09 & $<.0001$ & Yes \\
\hline \multicolumn{6}{|l|}{ Twitter } \\
\hline Enrollment & 3.14925 & 1.57128 & 2.00 & 0.0457 & Yes \\
\hline Faculty FT & 2.45313 & 178.609 & 0.01 & 0.989 & Yes \\
\hline Faculty FTPT & 28.32549 & 139.434 & 0.20 & 0.8391 & Yes \\
\hline Operating Budget & 0.00043496 & 0.00011 & 3.86 & 0.0001 & Yes \\
\hline \multicolumn{6}{|l|}{ Instagram } \\
\hline Enrollment & 0.38803 & 1.01926 & 0.38 & 0.7036 & Yes \\
\hline Faculty FT & 3.75879 & 115.244 & 0.03 & 0.974 & Yes \\
\hline Faculty FTPT & -5.64267 & 91.614 & -0.06 & 0.9509 & No \\
\hline Operating Budget & 0.0002801 & $7.10 \mathrm{E}-05$ & 3.97 & $<.0001$ & Yes \\
\hline \multicolumn{6}{|l|}{ LinkedIn } \\
\hline Enrollment & 6.37082 & 3.60808 & 1.77 & 0.0782 & Yes \\
\hline Faculty FT & 190.63002 & 398.445 & 0.48 & 0.6326 & Yes \\
\hline Faculty FTPT & -148.7569 & 307.44 & -0.48 & 0.6288 & No \\
\hline Operating Budget & 0.00099945 & 0.00024 & 4.11 & $<.0001$ & Yes \\
\hline
\end{tabular}

The tables 2 above show the regression analysis of the university characteristics where the explanatory variables are enrollment, faculty FT, faculty FT $+\mathrm{PT}$ and operating budget while dependent variables are 


\section{Issues in Information Systems}

Volume 22, Issue 4, pp. 126-142, 2021

the likes and followers on each of the social media platforms. Here, based on the results of the regression analysis, the two main characteristics that have significant impact on the likes and followers are enrollment and operating budget of the universities. The number of full-time faculty has an impact on followers of three of the social media platforms (Twitter, Instagram, and LinkedIn) with an exception for Facebook likes, whereas the universities that employ both full-time and part-time faculty significantly use Twitter. No significant impact of the same observed on the remaining three social media platforms (Facebook, Instagram \&LinkedIn). There is a significant effect of enrollments and operating budget on universities' social media presence. This was evident from the fact that a high operating budget has a higher number of likes and more enrollments had more likes in all the social media platforms. In other words, we can simply say that the typical value of the Facebook likes, Twitter, or Instagram or LinkedIn followers' changes with respect to the enrollment or operating budget of a university, whereas the full time faculties contribute towards the social media usage by interacting with students more on the three social media platforms other than Facebook. This might be due to less interaction of faculty on Facebook. In the other three social media platforms, it is possible that the faculty FT constantly and consistently interacted with students by engaging with them on their university webpage. The university characteristic faculty FTPT did not significantly correlate to the popularity of social media platforms, except in the case of Twitter. It could be because a greater number of part-time faculty interacted more on Twitter rather than on the other platforms.

Table 3: ANOVA Test Results of four social media platforms for the university characteristics Facebook, Twitter, Instagram and LinkedIn

\begin{tabular}{|l|l|l|l|l|l|l|}
\hline University characteristics & F-value & Pr>F & Significant & F-value & Pr>F & Significant \\
\hline Social media Platform & \multicolumn{5}{l}{ Facebook } & \multicolumn{5}{l|}{ Twitter } \\
\hline Region & 2.77 & 0.0267 & Yes & 2.74 & 0.0283 & Yes \\
\hline Type & 10.11 & 0.0016 & Yes & 5.19 & 0.0232 & Yes \\
\hline Level & 0.18 & 0.8317 & No & 1.86 & 0.1563 & No \\
\hline Program & 12.88 & 0.0004 & Yes & 31.69 & 0.0001 & Yes \\
\hline Social media Platform & Instagram & & LinkedIn & \\
\hline Region & 2.41 & 0.0485 & Yes & 2.58 & 0.037 & Yes \\
\hline Type & 3.31 & 0.0694 & No & 9.89 & 0.0018 & Yes \\
\hline Level & 0.43 & 0.652 & No & 1.75 & 0.1785 & No \\
\hline Program & 21.33 & $<0.0001$ & Yes & 13.61 & 0.0003 & Yes \\
\hline
\end{tabular}

The ANOVA test results of the four social media platforms for the university characteristics such as region, type, level and program displayed in the above table. Here, there are some significant differences are observed within regions with respect to the Facebook likes, and followers on Twitter, Instagram, and LinkedIn. For the Facebook likes, the significant comparisons $(<0.05)$ were found out to be in between Southwest-Midwest \& Southwest-Northeast. Similarly, for twitter followers, the significant differences were in between the regions Southwest-Northeast, Southeast-Northeast and West-Northeast. For Instagram followers, the significant differences were between Southwest-Northeast, Southwest-Midwest and 


\section{Issues in Information Systems}

Volume 22, Issue 4, pp. 126-142, 2021

Southeast-Midwest. Finally, for LinkedIn Followers, the difference $(<0.05)$ was in between southwest southeast and Midwest southeast. Therefore, from the above analysis it found that the maximum value of significance difference was in between Southwest-Northeast for all the four social media platforms. It assumes that a major number of universities that fall under these two regions. However, basically, when considering the region, the social media platforms popularly used in almost all the regions. Similarly, considering type, we see both public and private Universities adopt and utilize Facebook, Twitter and LinkedIn significantly, whereas Instagram found to promote less compared to Facebook, LinkedIn and twitter. It could also be because Instagram is the most recent platform among the four. Then, in case of level (GR, UG \& both), there was no significance found for all the social media platforms. It could be because any students from the university or outside can follow the specific social media platforms irrespective of their level of study. Finally, universities providing both business and accounting remarkably adopted all four social media platforms because students enrolled for business or accounting programs mostly followed or liked their universities' official social media accounts. 


\section{Issues in Information Systems}

Volume 22, Issue 4, pp. 126-142, 2021

Table 4: AACSB universities in USA on Facebook and Twitter social media platforms

\begin{tabular}{|c|c|c|c|c|}
\hline \multirow[b]{2}{*}{$\begin{array}{l}\text { S. } \\
\text { No }\end{array}$} & \multirow[b]{2}{*}{ Universities } & Facebook & \multirow[b]{2}{*}{ Universities } & Twitter \\
\hline & & $\begin{array}{l}\text { No of likes/No } \\
\text { of enrollment }\end{array}$ & & $\begin{array}{l}\text { No of } \\
\text { followers/No of } \\
\text { enrollment }\end{array}$ \\
\hline 1 & $\begin{array}{l}\text { North Dakota State } \\
\text { University, College of } \\
\text { Business }\end{array}$ & 0.06 & $\begin{array}{l}\text { Southern Utah University, } \\
\text { School of Business }\end{array}$ & 0.02 \\
\hline 2 & $\begin{array}{l}\text { Lehigh University, College of } \\
\text { Business and Economics }\end{array}$ & 0.11 & $\begin{array}{l}\text { St. John's University, The Peter } \\
\text { J. Tobin College of Business }\end{array}$ & 0.04 \\
\hline 3 & $\begin{array}{c}\text { Siena College, School of } \\
\text { Business }\end{array}$ & 0.15 & $\begin{array}{c}\text { Marist College, School of } \\
\text { Management }\end{array}$ & 0.06 \\
\hline 4 & $\begin{array}{c}\text { Grand Valley State } \\
\text { University, Seidman College } \\
\text { of Business }\end{array}$ & 0.28 & $\begin{array}{c}\text { Northwestern State University } \\
\text { of Louisiana, School of } \\
\text { Business }\end{array}$ & 0.11 \\
\hline 5 & $\begin{array}{l}\text { San José State University, } \\
\text { Lucas College and Graduate } \\
\text { School of Business }\end{array}$ & 0.31 & $\begin{array}{l}\text { New Mexico State University, } \\
\text { College of Business }\end{array}$ & 0.12 \\
\hline 6 & $\begin{array}{l}\text { Barry University, D. Inez } \\
\text { Andreas School of Business }\end{array}$ & 239.45 & $\begin{array}{l}\text { Nicholls State University, } \\
\text { College of Business } \\
\text { Administration }\end{array}$ & 95.78 \\
\hline 7 & $\begin{array}{c}\text { State University of New York } \\
\text { at New Paltz, School of } \\
\text { Business }\end{array}$ & 399.10 & $\begin{array}{c}\text { State University of New York } \\
\text { at New Paltz, School of } \\
\text { Business }\end{array}$ & 101.69 \\
\hline 8 & U.S. Coast Guard Academy & 419.41 & $\begin{array}{c}\text { Wichita State University, W. } \\
\text { Frank Barton School of } \\
\text { Business }\end{array}$ & 242.24 \\
\hline 9 & U.S. Air Force Academy & 533.34 & $\begin{array}{l}\text { State University of New York } \\
\text { College at Brockport, School of } \\
\text { Business and Management }\end{array}$ & 262.69 \\
\hline 10 & $\begin{array}{l}\text { State University of New York } \\
\text { College at Brockport, School } \\
\text { of Business and Management }\end{array}$ & 817.84 & $\begin{array}{l}\text { California State Polytechnic } \\
\text { University Pomona, College of } \\
\text { Business Administration }\end{array}$ & 1350.27 \\
\hline
\end{tabular}


Table 5: AACSB universities in USA on Instagram and LinkedIn social media platforms

\begin{tabular}{|c|c|c|c|c|}
\hline \multirow[b]{2}{*}{$\begin{array}{l}\text { S. } \\
\text { No }\end{array}$} & \multirow[b]{2}{*}{ Universities } & Instagram & \multirow[b]{2}{*}{ Universities } & LinkedIn \\
\hline & & $\begin{array}{l}\text { No of } \\
\text { followers/ } \\
\text { No of } \\
\text { enrollment }\end{array}$ & & $\begin{array}{l}\text { No of } \\
\text { followers/ No } \\
\text { of enrollment }\end{array}$ \\
\hline 1 & $\begin{array}{c}\text { The George Washington University, } \\
\text { School of Business and Illinois } \\
\text { Institute of Technology, Stuart } \\
\text { School of Business }\end{array}$ & 0.01 & $\begin{array}{l}\text { Marshall University, Lewis } \\
\text { College of Business }\end{array}$ & 0.04 \\
\hline 2 & $\begin{array}{c}\text { The Pennsylvania State University } \\
\text { Great Valley School of Graduate } \\
\text { Professional Studies, Great Valley } \\
\text { School of Graduate Professional } \\
\text { Studies }\end{array}$ & 0.03 & $\begin{array}{c}\text { Morehead State University, } \\
\text { College of Business and Public } \\
\text { Affairs }\end{array}$ & 0.06 \\
\hline 3 & $\begin{array}{l}\text { DePaul University, Richard H. } \\
\text { Driehaus College of Business }\end{array}$ & 0.04 & $\begin{array}{l}\text { Grand Valley State University, } \\
\text { Seidman College of Business } \\
\text { and Middle Tennessee State } \\
\text { University, Jennings A. Jones } \\
\text { College of Business }\end{array}$ & 0.07 \\
\hline 4 & Bentley University & 0.05 & $\begin{array}{l}\text { Oakland University, School of } \\
\text { Business Administration }\end{array}$ & 0.08 \\
\hline 5 & $\begin{array}{l}\text { North Carolina State University, } \\
\text { Poole College of Management }\end{array}$ & 0.07 & $\begin{array}{c}\text { North Carolina State } \\
\text { University, Poole College of } \\
\text { Management }\end{array}$ & 0.14 \\
\hline 6 & $\begin{array}{l}\text { University of California, Davis, } \\
\text { Graduate School of Management }\end{array}$ & 87.29 & $\begin{array}{c}\text { University of California, Davis, } \\
\text { Graduate School of } \\
\text { Management }\end{array}$ & 432.32 \\
\hline 7 & $\begin{array}{c}\text { Nicholls State University, College of } \\
\text { Business Administration }\end{array}$ & 97.38 & $\begin{array}{l}\text { The Pennsylvania State } \\
\text { University at Harrisburg, } \\
\text { School of Business } \\
\text { Administration }\end{array}$ & 451.65 \\
\hline 8 & $\begin{array}{l}\text { State University of New York at } \\
\text { New Paltz, School of Business }\end{array}$ & 125.66 & $\begin{array}{c}\text { University of California, San } \\
\text { Diego, Rady School of } \\
\text { Management }\end{array}$ & 458.50 \\
\hline 9 & $\begin{array}{l}\text { State University of New York } \\
\text { College at Brockport, School of } \\
\text { Business and Management }\end{array}$ & 238.38 & $\begin{array}{l}\text { The Pennsylvania State } \\
\text { University Great Valley School } \\
\text { of Graduate Professional } \\
\text { Studies, Great Valley School of } \\
\text { Graduate Professional Studies }\end{array}$ & 1406.00 \\
\hline 10 & U.S. Coast Guard Academy & 1496.45 & $\begin{array}{l}\text { State University of New York } \\
\text { College at Brockport, School of } \\
\text { Business and Management }\end{array}$ & 1730.04 \\
\hline
\end{tabular}


As the above table indicates, owners of the most popular fan pages are determined by the ratio of the number of fans or followers to the number of students enrolled (Skowera, K., \& Lukasik, K, 2016). This ratio measured in order to distinguish between the number of fans and the number of students because sometimes it is misleading that the number of likes depends on the number of students. This ratio also determines the popularity of the universities. If the ratio is greater than one (1) then the number of fans for that university is larger than its number of students. The top most ratios for State University of New York, College of Brockport, School of Business and Management, US Coast Guard Academy, The Pennsylvania State University Great Valley School of Graduate Professional studies are 1730.04, 1496.45, and 1406.00 respectively, measured on social media platforms LinkedIn, Instagram, and LinkedIn respectively. This also indicates that the number of fans being more than the number of students determines the popularity of these universities. The bottom three ratios are $0.01,0.02$ and 0.03 for The George Washington University, School of Business and Illinois Institute of Technology, Stuart School of Business, Southern Utah University, School of Business and The Pennsylvania State University Great Valley School of Graduate Professional Studies respectively. The 0.01 and 0.03 ratios are from Instagram and 0.02 ratio is from Twitter.

\section{Primary Findings and Implications}

\section{Discussion}

This study analyzed the level to which the universities in the US adopted and utilized social media platforms for communication by extracting data from Universities' official websites. The study concluded some primary findings such as 1) Social media is a fast and simple means of communication channel widespread across the US universities, 2) Adoption of the social media platforms varies across the universities and 3) Adoption and utilization of Social media is influenced by several university characteristics.

\section{Social media is a fast and simple means of communication channel widespread across the US universities}

There has been a monumental growth in the adoption and the utilization of social media in the last decade across the world, the dearth of prior studies that looked into this, especially with respect to universities in the United States. A study of an author's perspective observed for Polish universities is to know the usage of social media for technical universities and popularity by taking the average ratio by number of fans/number of students of the university (Skowera, K., \& Lukasik, K, 2016). Almost all universities have their profiles on each social media platform. The most popular social media platforms found out to be Facebook and LinkedIn. The study shows that LinkedIn has more followers than all other social media platforms. It has a high ratio of the number of followers to the number of students enrolled in that university, because more people are likely trying to use LinkedIn to build professional networks and connections. Being a professional networking platform, it favored many students \& Faculties (qs.com, University Social Media Marketing). Social media defines a fast and simple means of communication among students, faculty, and management to interact with one another. It is evident from a survey conducted by the Pew Internet \& American Life Project that reveals the usage of social network websites in online American youths ages 12-17 to be around 55\% (Lenhard and Madden, 2007).

\section{Adoption of the social media platforms varies across the universities}

An adoption in universities here reflects whether a university has set up an account and utilization allows to estimate how actively universities are using their accounts and on which the public respond to the posted content. A study conducted in two public universities in Nigeria reveals that socio-demographic variables have a positive impact on the usage and adoption of social media networks for the students in the 


\section{Issues in Information Systems}

Volume 22, Issue 4, pp. 126-142, 2021

universities (Olatokun and Ilevbare, March 2014). Although it is unclear which social networking platform may best associate universities with students and for what reason, it is plausible that students or parents will keep on interacting with universities through trending social media platforms like Instagram, Pinterest, and Snapchat. Especially for Facebook and Twitter, statistics around these interactions may empower universities to participate in exchanging and sharing information. These platforms offer universities a genuine opportunity to associate with students, construct a group and maintain a public front. To capitalize on it, universities should grasp social media and most of its advantages, while thinking about its present constraints (Cannon T, 2015).

\section{Adoption and utilization of Social media is influenced by several university characteristics}

The study also indicated that utilization of social media is more for Public Universities. They have more likes on Facebook and more followers on LinkedIn when compared to the private universities. While Facebook is useful for both personal and professional networking among the students \& the faculty, LinkedIn focuses primarily on professional networking and likewise by both public \& private universities.

When comparing the aforementioned universities' characteristics across the universities, similar characteristics compared and contrasted with one another. Moreover, all the four social media platforms are popular in their own way. LinkedIn found to be popular among graduate and undergraduate level of students. Most of the students start focusing on their professional fields after completing studies. LinkedIn is a very effective platform that enables them to build strong professional networks. This can be evident based on the aforementioned ratio values for this platform, as more profile users on this platform followed each other to build social and professional networks.

Universities with both Business and accounting programs have a greater number of followers than only business schools, especially in Twitter. Finally, the utilization of social media varied across the regions in the US. In the Southwest region, Facebook and Instagram are popular whereas Twitter and LinkedIn are popular in the Midwest. Therefore, all the four social media platforms have gained popularity across the universities. Facebook and LinkedIn, in particular, gained a lot of interest from students and faculty. This was evident in the in-house observations of the business schools in the AACSB article that states that Facebook and LinkedIn are top most popular social media platforms (Morris, 2012). There is no doubt that these platforms help students by providing knowledge as well as building strong professional networks faster than any other traditional methods.

This study provides significant implications for research. It gives guidance to the students $\&$ faculties to use social media efficiently. It recommended for universities to adopt social media. They should create and update their profiles on social media and consistently keep a two-way communication for productive purposes. That not only builds relationships between students $\&$ faculty but also improves networking with some well-known organizations helping them build their career.

\section{Conclusion}

Social media platforms are widespread, and few are at their transition stage for penetrating into the market. Adoption and utilization of these platforms are popular among the people in the universities. This study concluded that the adoption and utilization of social media is significant in public and both (business \& accounting) when compared to other groups. By performing ANOVA and regression analysis, it inferred that the enrollment and operating budget university characteristics play a significant role towards the number of likes or followers. That is likely because, the more the number of students, the more budget for operations and therefore, more likes or followers. In addition, faculty FT has a significant impact on three 


\section{Issues in Information Systems}

Volume 22, Issue 4, pp. 126-142, 2021

platforms other than Facebook whereas faculty FTPT has a significant effect only on Twitter. With an exception of Instagram, all the other three social platforms show a similar trend with respect to the university characteristics such as region, type, level, and program. No prior research that reviewed the functional purposes of social media use in the US universities, and its impact and opportunity on students and faculty remain largely unknown. This kind of trending communication channel (social media) can be the primary channel for establishing relationships between students/parents, faculty, and universities. Another interesting fact mentioned by the AACSB counselors is that students, especially businesses are encouraged to follow their favorite companies on the news and social media platforms (Best business schools, aacsb.edu). In addition to that, by looking at the past literature and the associated statistics around social media usage, it recommends as a powerful communication channel that should be interactive (twoway communication); universities can look for prospective candidates that are best suitable for a program. Social media may be a communication strategy to improve marketing (brand image and recruitment) and sophisticated and trending technologies that keep the university sustained and help produce skilled graduates in the society.

\section{Limitation}

This study is just a snapshot of universities' adoption and utilization of social media. Social media platforms are constantly evolving, just like technology and media channels. Only AACSB accredited universities for the US region are considered. There are many other universities across the United States and across the globe. The study here might or might not generalize to the rest of the universities just because they could be using different social media channels/platforms/interactions to enroll their prospective students.

\section{Future scope}

There are no specific studies carried out in the context of social media in US universities. This study is just a snapshot of the adoption and utilization of social media across US universities. Similar studies carried out as longitudinal study with different kinds of social media platforms across the globe. An extension to this study can be to find if the results show similar pattern for business and both categories under program.

A more elaborate study covering even non-AACSB accredited universities, would uncover newer findings and more generalized results. Also, the manual process that is used in this study for uncovering social media accounts of universities from their websites can be improved to get usable data for study for the AACSB universities that weren't included in this study. Doing so, would improve the coverage of the results of this work. The social media profile inquiry technique used in this work, nonetheless, imitates the procedure that people in general may use to look for the web-based social networking website page for a given university. Finally, the results and findings of this study can further be analyzed/adopted to help universities improve their communication outreach to students, parents and faculty.

\section{References}

Aslam, S. (2021, January 6). • Instagram by the Numbers (2021): Stats, Demographics \& Fun Facts. Omnicore. https://www.omnicoreagency.com/instagram-statistics/

Bernardo, E. V. (2015, August 7). Why Universities Need to Get Social. WIRED. https://www.wired.com/insights/2013/06/why-universities-need-to-get-social/ 


\section{Issues in Information Systems}

Volume 22, Issue 4, pp. 126-142, 2021

Brendzel-Skowera, K., \& Łukasik, K. (2016). Polish Universities in Social Media. Valahian Journal of Economic Studies, 29-36.

https://scholar.google.com/scholar?oi=bibs\&cluster=193399633782973696\&btnI=1\&hl=pl

Bruner, R. (2016, July 16). A Brief History of Instagram's Fateful First Day. Time.

https://time.com/4408374/instagram-anniversary/

Cannon, T. (2019, February 4). How are universities using social media? Red Brick Research. https://www.redbrickresearch.com/2015/07/27/how-are-universities-using-social-media/

Gregersen, E. (2021, May 13). LinkedIn | Overview, History, \& Facts. Encyclopedia Britannica. https://www.britannica.com/topic/LinkedIn

Griffis, H. M., Kilaru, A. S., Werner, R. M., Asch, D. A., Hershey, J. C., Hill, S., Ha, Y. P., Sellers, A., Mahoney, K., \& Merchant, R. M. (2014). Use of Social Media Across US Hospitals: Descriptive Analysis of Adoption and Utilization. Journal of Medical Internet Research, 16(11), e264. https://doi.org/10.2196/jmir.3758

Hashim, H., Ahmad, B. E., Abdullah Baharum, M. A., Ismail, M. R. (2018). Proceedings of the Regional Conference on Science, Technology and Social Sciences (RCSTSS 2016): Social Sciences. Germany: Springer Singapore

Karadkar, A. (2015, September 13). The impact of social media on student life. TECHNICIAN. https://www.technicianonline.com/opinion/article_d1142b70-5a92-11e5-86b4cb7c98a6e45f.html

Lenhart, A., \& Madden, M. (2007, January 7). Social Networking Websites and Teens. Pew Research Center: Internet, Science \& Tech. https://www.pewresearch.org/internet/2007/01/07/socialnetworking-websites-and-teens/

Lunden, I. (2014, January 21). Instagram Is The Fastest-Growing Social Site Globally, Mobile Devices Rule Over PCs For Access. Techcrunch. https://techcrunch.com/2014/01/21/instagram-is-thefastest-growing-social-site-globally-mobile-devices-rule-over-pcs-for-social-access/

MacArthur, A. (2020, September 11). The History of Twitter You Didn't Know. Lifewire. https://www.lifewire.com/history-of-twitter-3288854

Montoneri, B. (2013). Impact of LinkedIn on Boosting Students' Learning Motivation and Career Prospects. COLLA 2013 : The Third International Conference on Advanced Collaborative Networks, Systems and Applications, 24-27. http://dspace.lib.pu.edu.tw/handle/123456789/16596

Moody, J. (2019, August 22). Why Colleges Look at Students' Social Media. US News. https://www.usnews.com/education/best-colleges/articles/2019-08-22/why-colleges-look-atstudents-social-media-accounts

Morris, S. (2012, November 1). Social Media: How Tweet It Is | BizEd Magazine. BizEd AACSB International. https://bized.aacsb.edu/articles/2012/11/social-media-how-tweet-it-is 


\section{Issues in Information Systems}

Volume 22, Issue 4, pp. 126-142, 2021

Noyes, D. (2021, June 7). The Top 15 Valuable Facebook Statistics - Year in Review. Zephoria Inc. https://zephoria.com/top-15-valuable-facebook-statistics/

Olatokun, Wole \& Ilevbare, Godson. (2014). Probing university students' adoption and utilization of social networking websites in Nigeria. Annals of Library and Information Studies. 61. 15-23

Phillips, S. (2017, July 15). A brief history of Facebook. The Guardian. https://www.theguardian.com/technology/2007/jul/25/media.newmedia

Picard, A. (2011, March 21). The history of Twitter, 140 characters at a time. The Globe and Mail. https://www.theglobeandmail.com/technology/digital-culture/the-history-of-twitter-140characters-at-a-time/article573416/

QS Digital Marketing \& QS Digital Marketing. (2018, February 2). University Social Media Marketing: Who's Getting It Right? QS. https://www.qs.com/university-social-media-marketing-whosgetting-it-right/

Ridley, D. (2016, April 5). Today's Colleges and Universities Using Social Media. Vital Design. https://vtldesign.com/digital-marketing/social-media/how-todays-colleges-and-universities-areusing-social-media/

Social Media Fact Sheet. (2018, April 6). Pew Research Center: Internet, Science \& Tech. https://www.pewresearch.org/internet/fact-sheet/social-media/

Statista. (2021a, January 27). Number of monthly active Instagram users 2013-2018. https://www.statista.com/statistics/253577/number-of-monthly-active-instagram-users/

Statista. (2021b, May 21). Facebook: number of monthly active users worldwide 2008-2018. https://www.statista.com/statistics/264810/number-of-monthly-active-facebook-users-worldwide/

Wang, Q. (2011). The Effects of Social Media on College Students. ScholarsArchive@JWU. https://scholarsarchive.jwu.edu/mba_student/5/

Writers, S. (2020, November 30). Colleges Dominating Social Media | BestColleges. BestColleges.Com. https://www.bestcolleges.com/features/best-college-social-media/ 